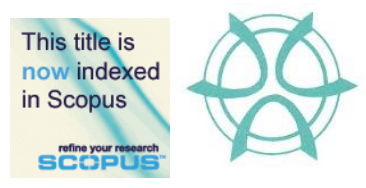

PLANNING MALAYSIA:

Journal of the Malaysian Institute of Planners

VOLUME 15 ISSUE 1 (2017), Page 169 - 178

\title{
A REVIEW INTO THE "ISLAMIC" TRADITION IN THE MUGHAL GARDEN: (RE)SHAPING OUR STAND ON ISLAMIC ART AND \\ DESIGN
}

\author{
Zainab Abdul Latiff ${ }^{1}, \&$ Maheran Mohd Yaman ${ }^{2}$ \\ ${ }^{I}$ Faculty of Design and Architecture, \\ UNIVERSITI PUTRA MALAYSIA \\ ${ }^{2}$ Kulliyyah of Architecture and Environmental Design, \\ INTERNATIONAL ISLAMIC UNIVERSITY MALAYSIA
}

\begin{abstract}
In the field of garden history, Mughal gardens represent a prominent chapter of what is often called the Islamic garden tradition. Most previous studies have discussed on its theories and principles. However, it is essential to establish the physical characteristics of the Mughal garden as representing Islamic garden tradition. The method of content analysis has been applied in this study. The study found that Mughal garden design is much influenced by the Persian's Chāhār Bāgh, Hindu mythology and Quranic paradise imagery. To conclude, Mughal garden design needs to be assimilated into the current culture of local people within the established principles of environment in Islam.
\end{abstract}

Keyword: Mughal garden, contemporary garden, Islamic garden, culture, Islamic principles

Date Received: $30^{\text {th }}$ April 2016

Date of Acceptance: $30^{\text {th }}$ October 2016 
Zainab Abdul Latiff, \& Maheran Mohd Yaman

A review into the "Islamic" tradition in the Mughal garden: (Re) shaping our stand on Islamic art and design

\section{INTRODUCTION}

The origin of Mughal gardens can be traced to central Asia, while the climax was reached in India over a long period of time (Koch, 1997a). Mughal gardens were influenced by gardens of other regions and times such as regional influences from central Asia, Kashmir, western Punjab, Persia and Delhi sultanate (Wescoat, 1996). Mughal gardens had always had a powerful impact on architectural history and design as one of the pre-eminent expression of Islamic art, culture, and values. It represents the extraordinary synthesis of human concerns. It integrates the finest features of natural and built environments with the finest traditions of local and regional landscape design. They draw together human aspirations for worldly spiritual order by merging the Paradise imageries with real garden design on earth (Wescoat, 1996).

\section{OBJECTIVE OF THE STUDY}

The main objective of the study is to dispute the assignment of the Mughal garden as representing the Islamic garden.

\section{METHODOLOGY OF THE STUDY}

The methodology followed in this study is mainly content analysis and library search that emphasized on the theories and principles of the Mughal garden.

\section{THEORIES AND PRINCIPLES OF THE MUGHAL GARDEN}

Mughal gardens are primarily situated along the plains of India and Kashmir. The climate of the area is tropical and winds are warm and dry (Lehrman, 1980). The most important aspect of Mughal gardens is that the built environment remained very closely wedded with the natural ingredients such as plants, lights of the sunshine and the moon, the songs of the birds and movements of the air saturate with the garden environment (Koch, 1997b). Man-made structures were organized in such a way that one felt to be in an idealized natural environment. The built environment captured the harmony which existed within nature. Similarly, man-made elements such as aiwans, streams, fountains, walkways and lamps coexisted simultaneously with natural elements. The individual elements formed a whole, and the whole was always subordinate to nature. Therefore, gardens were actually used as places of enlightenment, meditation and revelation (Ashtiani \& Sadat, 2015; Asher, 2003).

The Mughals were Persianised Turks originated from Central Asia and brings Persian culture to India (Dickie, 1985). Babur (1526-1530), the first Mughal Emperor (Lehrman, 1980; Koch, 1997b) was directly descended from Genghis Khan and Tamerlane (Koch, 2008). The sensational conquests of his great ancestor over a century before had brought together Central Asia, North 
India, Persia, Mesopotamia, Syria, and Asia Minor in a single empire with its capital at Samarkand, and subsequently Herat (Dickie, 1985). This is evidenced in the remarkable similarity of garden layout and planning over a vast geographical territory and time period, despite wide variations in local culture and technological contexts (Blair \& Bloom, 2003). The Mongols had no real culture or well-defined religion of their own and they readily adopted those of the country they conquered. To embellish his capital of Samarkand, Babur imported garden designers from Central Asia, as one of his initiatives to develop a garden (Jaffar, 1936).

India was first ruled by Babur (1526-1530) followed by Humayun (15301556), Akbar (1556-1605), Jahangir (1605-1627) and ended by Shah Jahan (1627-1657). Of these five emperors, Babur, and his great-grandson, Jahangir was the most passionate nature lovers and the most renowned garden builders (Moynihan, 1980). Gardens were the new centres of royal power (Petruccioli, 1997) during their time. Therefore, the tradition of formal gardens in the Indian subcontinent started with the arrival of the Mughals.

The Mughals were justifiably known as some of the history's greatest patrons of gardens. Before the establishment of Mughal rule, the sites for recreation and pleasure activities were mostly informal and situated in the suburbs of residential settlements or near water sources. Planned landscape features existed in and around shrines, temples and water bodies. The objectives of such formal and informal spaces were to bring the human mind and soul closer to nature. The Mughals gave a new image of the landscape to areas occupied by them. Gardens were built within towns, in suburbs, and along major highways (Mubin, Gilani \& Hasan, 2013).

One of the significant features of Mughal gardens is that they are mostly used during the evenings rather than day time. This is exhibited in the extensive use of lamps and moonlight in the gardens. The sensory qualities of landscape elements in the Mughal gardens made up its ambience (Petruccioli, 1998; Wescoat, 2011).

The earliest Mughal garden was of Babur's, located in Agra; was laid out in an urban context in a deliberate opposition to the citadel-palaces or forts, built by pre-Mughal rulers (Asher, 2003; Md Jani et al., 2015; Wescoat, 2011). The Ram Bagh of Agra came into the picture when Babur visited Timurid and Uzbek gardens in Samarkand, Kabul and Herat before coming to Hindustan. $\mathrm{He}$ was amused by Samarkand's fascinating gardens that stimulated him in developing his own garden (Titley, 1979). Babur was interested in the garden as an object of beauty and a means of delight, rather than as a man-made reflection of the Quranic image of paradise. The open layout and greater architectural character have eventually been so typical of the Indian garden (Ansari, 2011; Ashtiani \& Sadat, 2015; Asif et al., 2015; Esmaili, 2014). 
Zainab Abdul Latiff, \& Maheran Mohd Yaman

A review into the "Islamic" tradition in the Mughal garden: (Re) shaping our stand on Islamic art and design

Most of Babur's gardens were in the hilly country, with abundant streams which then Babur ordered to be diverted into straight watercourses and rectangular basins. It was this concept of orderliness and symmetry which he carried with him to India (Dale, 2004; Gilliat-ray \& Bryant, 2010; Mirza, 2015). However, Babur's craftsmen from Persia and Central Asia brought the Islamic garden tradition of order, geometry, symmetry, straight channels and rectilinear pools but also absorbed local custom. On the other hand, Hindu craftsmen introduced an organic quality (Dickie, 1985; Rehman, 2013; Rehman \& Akhtar, 2012). The basic plan and other elements of the Mughal garden are influenced from the earlier gardens in Turkestan and Persia, especially the Chāhār Bāgh or fourfold garden layout (Gilliat-ray \& Bryant, 2010; Brooks, 1988; Stronach, 1994).

Mughal gardens took a great advantage of the natural feature in the landscape by erecting gardens of three types; first, gardens within the palace courts; second, gardens that surrounded tombs and third are the gardens of large charbaghs or paradise gardens (Moynihan, 1980). Tomb gardens recalled an earlier Persian garden design with no terraces, only a slight slope and shallow changes in the level for the gravity-fed water system. Its layout was a square with multiple divisions of plots in the four quarters. While, the layout of paradise garden is a parallelogram with four-square gardens on each terrace (Dickie, 1985; Wescoat, 2011; Moynihan, 1980; Mughal, 2011).

Water dominated all Mughal gardens. The heart of their charbaghs was the central watercourse. The early gardens depended on upon wells, later in canals, as a more dependable water supply followed by widening of the watercourses studded with fountains. These charming water gardens in a waterless landscape provided the user with a scene of sensational and poetic (Moynihan, 1980; Rehman, 2013).

Relating to the concept of Quranic paradise imagery in Mughal garden, Mr. Sajjad Kausar in his publication on Shalamar garden made this comparison by stating that, "The Islamic garden tradition...can be traced in all Mughal gardens...that often represent those of the Quranic gardens of paradise" (Moynihan, 1980).

"Mughals gardens were full of symbolism delineate the culture of the local people. For example, the terraces in the gardens represented those of the Quranic garden of paradise. Superstitious, but religious at the same time, some of the emperors sought guidance from the stars and occasionally built their charbaghs to conform to the number of planets and signs of the zodiac. The number nine and eight have a special meaning to the Mughals which always be crystallized onto gardens spatial element designs."

Moynihan (1980) 
PLANNING MALAYSIA

Journal of the Malaysia Institute of Planners (2017)

In contrast, Brookes (1988) opposes to that by stating that, "Islamic art (in India) was the very antithesis of Hindu art; for Hindu adornment was individualistic, irregular and symbiotic, while Islamic decoration was mathematical, continuous and abstract" (Moynihan, 1980). The early Mughal gardens had more vitality and a stronger character than the later, more voluptuous gardens (Moynihan, 1980; Ross, 1931). It is evident in the reflection of wealth and security in Mughal buildings. Also, the structures of gardens became more palatial, light silken awnings and other features emulating an increase in extravagance. These mutual influences of garden and palace culminated in Shah Jahan's palace in the Red Fort of Shahjahanabad in Delhi, which was not a palace at all but a terrace of luminous marble pavilions linked by gardens and watercourses (Stuart, 1913).

The Mughal garden was developed for two purposes; to serve as a mausoleum and those developed for pleasure. The Mughal mausoleum set in its garden was not derived from Iranian precedents; it is more likely to have evolved from Mongol tradition or even from Hindu mythology. A garden would be developed during the owner's lifetime when the building at its centre was possibly used for receptions and banquets, and then converted into a mausoleum upon his death. The second purpose is to suit the Islamic style of gardening to create pleasure gardens in a summer resort with fertile plains, green hills and springs outpouring, where it is described by Jones Lehrman "as a natural paradise on earth" (Baarah, 2010).

The courtyards were also largely for pleasure when they were designed as small enclosed gardens with water, grass and shade. Courtyards in the mosque were still well designed and executed, paved and contained an ablution basin in the centre (Lehrman, 1980). A Mughal garden is always rectangular in shape, accessible (Dickie, 1985), terraced and had pavilions and avenues lined with trees and fountain and bore Iranian names. The focus of the design of the pleasure garden was a pavilion that was inspired from the Chahār-Bāgh layout in Chihil Sutun. Therefore, the Chahar Bagh layout was used only to refer to Timurid gardens or to those of Babur's (Jaffar, 1936; Rehman, 1997).

Meanwhile, gardens in the plains were more related to the traditional formal paradise layout and were primarily the setting for magnificent buildings. The development of the pleasure garden, on the other hand, largely reflected the regard felt by the Mughal Emperors for Kashmir, where many such gardens were established. The rulers of the Mughal Empire built grand palaces and gardens which were usually adaptations of the Mughal style after the empire weakened resulting in the decline of its architecture. These palace gardens were built without the application of strong axial symmetry and the use of water in them diminished or in other words, Chahār-Bāghs were no more plays the role of the 
Zainab Abdul Latiff, \& Maheran Mohd Yaman

A review into the "Islamic" tradition in the Mughal garden: (Re) shaping our stand on Islamic art and design

garden's prototype. The great Mughal period ended after the death of Shah Jahan (Moynihan, 1980; Stuart, 1913).

The Islamic characteristics in the Mughal garden are, in fact the influence of Timurid gardens. This tradition was brought to the south to produce the Persian garden and to east to produce the Mughal garden, which are mostly located in palaces (Moynihan, 1980; Stronach, 1994; Stuart, 1913; Wescoat, 2011). As a consequence, the introduction of lush gardens of Central Asia into the dusty plains of India produced a mixture of garden (Dickie, 1985; Hamed, 1994). Babur ruled Afghanistan for 22 years (Titley, 1979). His first garden there was inspired by a Timurid model. It was built more as a residential environment that consists a sitting place, enjoyment hall, horse stables, camping place, a splendid gateway and an abundance of cherry trees, orange trees, sugar cane and pomegranates in a Chāhār Bāgh layout (Rehman, 1997; Rehman \& Akhtar, 2012).

Meanwhile, Babur's first garden in India, the Ram Bagh was designed by himself in an orderly and symmetrical way (MacDougall \& Ettinghausen, 1976) with a square pool often placed at the junction of two waterways (Rehman \& Akhtar, 2012) as well as a pleasure house in the centre. There was a stone platform for sitting, shaded by a canopy. The platform is placed in front of the first pavilion, and close to a pool. Steep terracing became characteristic of his design, and he apparently never built a garden without water (Moynihan, 1980). The attractive border area contained plantings. The other pavilion is slightly larger and is most likely of a type which backs onto the garden wall and has a small rectangular room in the rear. Monumental gates were essential components (Rehman, 1997).

Columns and flowers were carved. There were also two pavilions along the waters' edge and a few courtyards. There were trees and flowers, two fountains and square stone tanks with coloured tiles and fountains (Moynihan, 1980; Titley, 1979). There were constant movement and sparkle of water (the hilly landscape encouraged the introduction of waterfalls), cascades, stone-lined water channels, water chutes, mausoleum or kiosk, cisterns, and wells. There was also a geometrical pattern of raised walks and platforms. The walks are some ten feet above ground level and about eight feet wide, with narrow irrigation channels down the centre to water the trees planted at intervals along the walks. At the corner of the pavements are stone platforms surrounded by narrow watercourses which can be found in almost all Mughal gardens.

Mughal gardens are always in a series of ascending terraces, and this concept was followed in many later gardens. The first level was open to the public, the second was the emperor's private garden, and the third was the zenana garden for the harem. A Mughal garden could have eight terraces, which followed the Islamic concept of paradise in eight divisions. Among the examples of 
PLANNING MALAYSIA

Journal of the Malaysia Institute of Planners (2017)

Mughal gardens are Bagh i-Wafa (garden of fidelity), Nimla, Kashmir Shalimar Bagh, Nishat Bagh, Lotus Garden, Sheikhpura (today Pakistan) which is similar to pairidaeza of the Sassanian kings of Persia ${ }^{26}$ and others. Alternatively, a garden could have seven divisions which then reflected the seven planets. There was little consistency; Nishat Bagh in Kashmir was given twelve divisions one for each sign of zodiac (Ruggles, 2008).

The manipulation of water through channels was sometimes laid at rightangles to the main water course and conformed to the traditional fourfold division. These channels were paralleled by straight paths (MacDougall \& Ettinghausen, 1976; Mirza, 2015), grassed area, edged with narrow flower beds shaded by straight rows of imposing trees. The garden was enclosed by massive walls, which gave a sense of privacy and peace. The walls were a shield against the hot winds of summer and the brown land. There were lofty gateways centred on the wall, contained huge wooden doors, studded with heavy iron bosses, nails and spikes. Regular avenues led from the gateway or flanking pavilion to a central structure in front of which were rectangular water tanks. Water flowed through carved inclined planes or chutes (chadar) from one terrace level to the next. The channels of the early Mughal gardens were narrow and shallow, with broad areas of paving on each side. The secondary channels led from the main ones. As Mughal garden design evolved, the channels became wider. The base of the channels was sometimes inlaid with zig-zag stripes of dark marble to symbolize the movement of the waves as the water flowed through (Ansari, 2011; Ashtiani \& Sadat, 2015; Asher, 2003).

The Mughal gardens were also planted with imported trees such as poplar, oriental plane or chenar, dark cypress, willow and the massive chenar. Roses and narcissus were also planted. Locally grown fruit trees are also planted such as apples, oranges, figs, mangoes, coconuts, bananas, mulberries, lime, quince, apricot, cherry, plum, peach, guava, pear, pomegranate, and tamarind. Flowers that were cultivated were roses, violets, sunflowers, jasmine, marigolds, poppies, carnations, hollyhocks, wallflowers, delphiniums, hibiscus, hyacinths, jasmine, lilies, narcissus, lotus, lilacs and tulips, which were all watered by hand during the extensive dry season. Iris has been the substitute of myrtle; frequently present in Mughal iconography. For irrigation purposes, artificial lakes, canals and wells with raised water by an arrangement of wheels and levers was used for many years before Mughal (Lehrman, 1980).

Mughal garden is usually in a square or rectangular shape with rows of trees and flowerbeds, centrally placed canals, waterfalls and running fountains (Mughal, 2011). The gardens had Chāhār Bāgh layout (Wescoat, 2011) which was originally inspired from Iran, and brick-lined walkways and causeways. A high wall, adorned with serrated battlements and pierced by a lofty entrance gateway, encircles the garden. In larger gardens there are always four main gateways or buildings. The water runs into a trim stone or brick-edged canal down 
Zainab Abdul Latiff, \& Maheran Mohd Yaman

A review into the "Islamic" tradition in the Mughal garden: (Re) shaping our stand on Islamic art and design

the whole length of the enclosure, falling in cascades, or rushing over carved water-chutes (cedars) then ended up in a larger or smaller tank, usually studded with numerous small fountains (Ali, 2003).

The principal pavilion was often placed in the centre of the largest of these sheets of water. There are also side-canals, leading out from the principal into the wall, raised platforms (Rehman \& Akhtar, 2012) and gateways. From these stone-bordered canals and tanks, the water required for irrigating the soil is conducted by pipes. Avenues of plane and cypress trees were planted in the square plots intersected by watercourses which were filled with fruit trees and parterres of flowers. There were shady walks, pergolas of vines and flowers; turfed open squares shaded by large trees planted at the corners, or having one central chenar or mango tree surrounded by a raised platform of masonry or grass, terraces, fountains, and narrow watercourses, with their tiny, carved water-chutes, and the old well from which the garden was supplied with water from the Jumna (Dale, 2004).

Water chutes are used in a series of high terraces (Dale, 2004; Wescoat, 2011). But in small gardens, or in the plains, even the slightest slope was made into little waterfalls. A small pavilion built on the terrace at the far side of the garden. There are two large sunk plots on the garden's site. This enclosure, square plots, narrow watercourses, raised paths, sunken flower beds, continuous parterres, lowered square garden, flower beds that contain rose bushes, fruit trees, and tall-growing flowers and herbs. The large fountain basins and tanks were designed in the same fashion, their corners and sides being ornamented with scrolls of sculptured stone or marble, wide terraces with lines of little fountains and broad pathways (Mirza, 2015; Nath, 1982; Petruccioli, 1998).

The early Mughal gardens in India followed closely on their Persian origin. It is essentially a terraced garden. Water was manipulated beautifully in canals, jets of water, waterfalls, cascades, ponds and lakes (Nath, 1982). "The central artificial pool was highly appreciated as a place of relaxation and as a setting for court ceremonials" (Ross, 1931). Here the paved walkways are raised some ten feet above the level of the beds. The height above the flowerbeds varied according to what was intended to be planted in the garden: thus, some gardens were quite shallow while others were very deep. Thus, the Indo-Islamic garden operated simultaneously on two levels: visually, on the upper level, as a living carpet; and, sensually, on a lower plane, as a place of shade and intimacy and cool repose. It could only operate visually as a floral carpet or actually as a refuge from the scorching heat provided the planting was dense (Rehman, 1997).

\section{CONCLUSION}

Mughal garden is one of the great gardens in the Muslim world, which was largely constructed to serve the emperors or sultans. The garden was generally built in a 
palatial environment, influenced by the ancient culture and traditions of the Persians as well as local cultures of Hinduism. Though the Quranic concept can be traced in all parts of the garden, the garden does not stand on glorifying the Quranic imageries alone, but mixed with local culture, which is obviously beyond Islamic doctrine. It is essential to note that, nothing on earth is equivalent to the paradise promised to the believers by the Almighty Allah (SWT), what more to equalize a man-made (restructured) environment to a paradise, which appearance is undoubtedly incomprehensible by a normal person's mind. Indeed, as indicated in the article; Mughal garden apparently has gone through a series of transformation from a nature-appreciation landscape, during the reign of the first emperor, Babur, to a voluptuous garden in the reign of the last emperor of Mughal, Shah Jahan. Secondly, the implication of culture in the garden is discernible throughout its construction and design. The construction and arrangement of the built structures, vegetation, water elements, location, materials used, pre-determined layout and other physical features in the garden should be assimilated into contemporary garden design according to local context, preferences, religious affiliation as well as the underlying environmental principles in Islam, such as unity (tawhid); creation (fitra); balance (mizan); and responsibility (khalifa) (Khalid, 2010; Abdul Latiff \& Mohd Yunus, 2016).

\section{REFERENCES}

Abdul Latiff, Z., \& Mohd Yunus, M. Y. (2016). The Islamic Garden design principles: thoughts for the 21st century. Research Journal of Fisheries and Hydrobiology, 11(3), 175-178.

Ali, D. (2003). Gardens in early Indian court life. Studies in History, 19(2), 221-252.

Ansari, N. (2011). The Islamic garden (seminar paper). CEPT University, Gujarat, India.

Ashtiani, M. \& Sadat, F. (2015). Principles for designing a modern Islamic garden. How can new design contain the memory of the past? (Master's thesis). University of Illinois at UrbanaChampaign.

Asher, C. B. (2003). The new Cambridge history of India architecture of Mughal India. In G Johnson, C. A. Bayly \& J. F. Richards (Eds.). United Kingdom: The Press Syndicate of the University of Cambridge.

Asif, N., Utaberta, N., Othman, M. A., \& Mohd Yunos, M. Y. (2015). Redefining Islamic garden: comparative analysis of approaches, ideas and design framework." Jurnal Teknologi 75(9), 77-81.

Baarah, S. A.(2010). Gardens in Islamic architecture: an analytical study (Thesis). An-Najah National University, Nablus, Palestine.

Blair, S. S., \& Bloom, J. M. (2003). The Mirage of Islamic Art: Reflections on the Study of an Unwieldy Field. The Art Bulletin, 85(1), 152-184.

Brooks, J. (1988). Gardens of Paradise: the history and design of the great Islamic gardens. New York: New Amsterdam Books.

Dale, S. F. (2004). The garden of the eight paradises. Leiden: Koninklijke Brill.

Dickie, J. [Yaqub Zaki] (1985). The Mughal garden: gateway to paradise. Muqarnas, 3, 128-137.

Esmaili, M. (2014). The impact of Persian architecture on the Indian architecture. Journal of Life Science and Biomedicine, 4(4), 286-289.

Gilliat-ray, S., \& Bryant, M. (2010). Islamic gardens in the UK: dynamics of conservation, culture and communities. Retrieved from es.cardiff.ac.uk/islamukcentre/research/islamic-gardens/

Hamed, S. (1994). Paradise on earth: historical gardens of the arid Middle East. Desert Architecture III: Building a Sustainable Future Paradise, 36, 1-8. 
Zainab Abdul Latiff, \& Maheran Mohd Yaman

A review into the "Islamic" tradition in the Mughal garden: (Re) shaping our stand on Islamic art and design

Husain, A. A. (2000). Scent in the Islamic garden: a study of Deccani Urdu literary sources. Karachi: Oxford University Press.

Jaffar, S.M. (1936). The Mughal Empire from Babur to Aurangzeb. Peshawar: S. Muhammad Sadiq Khan Kissa Khani.

Khalid, F. (2010). Islam and the environment: Ethics and practice. The 15th General Conference the Environment in Islam. Amman, Jordan.

Koch, E. (2008). Mughal Imperial Architecture (1526-1858 A.D). Retrieved from https://isites.harvard.edu/fs/docs/icb.topic771131.files//Past_Syllabi/HAA183.pdf.

Koch, E. (1997a). Mughal Palace Gardens from Babur to Shah Jahan (1526-1648). Muqarnas, 14, 143-165.

Koch, E. (1997b). The Mughal waterfront garden. In A. Petruccioli (Ed.) Gardens in the time of the great Muslim empires: theory and design, pp. 140-160. Leiden; New York: E.J. Brill.

Lehrman, J. B. (1980). Earthly paradise: garden and courtyard in Islam. University of California Press.

MacDougall, E. B., \& Ettinghausen, R. (1976). The Islamic Garden. Dumbarton Oaks Colloquium on the History of Landscape Architecture, 4

Md Jani, H. H., Harun, N. Z. Mansor, M., \& Zen, I. (2015). Exploring the Islamic Garden concept as inspirational landscape design. Procedia - Social and Behavioral Sciences, 170, 359-368.

Mirza, M. (2015). Paradise on Earth. University of Manitoba Winnipeg, Manitoba, Canada.

Moynihan, E. B. (1980). Paradise as a garden: in Persia and Mughal India. London: Scholar Press.

Mubin, S., Gilani, I. A., \& Hasan, W. (2013). Mughal gardens in the city of Lahore - a case study of Shalimar Garden material \& methods. Pakistan Journal of Science, 65(4), 511-522.

Mughal, M. R. (2011). Impact of urbanization on ancient gardenscape of Lahore and the World Monument of Shalimar Garden (Pakistan). 15th ICOMOS General Assembly and International Symposium: 'Monuments and sites in their setting - conserving cultural heritage in changing townscapes and landscapes', Xi'an, China.

Nath, R. (1982). History of Mughal architecture (Volume 1). Abhinav.

Petruccioli, A. (Ed.) (1997). Gardens in the time of the great Muslim empires: theory and design Leiden; New York: E.J. Brill.

Petruccioli, A. (1998). Rethinking the Islamic Garden. Yale F \& ES Bulletin, 10, 349-364.

Rehman, A. (2013). Changing concepts of garden design in Lahore from Mughal to contemporary times." Garden History, 37(2), 205-217.

Rehman, A. (1997). Garden types in Mughal Lahore according to early seventeenth century written and visual sources. In A. Petruccioli (Ed.) Gardens in the time of the great Muslim empires: theory and design. Leiden; New York: E.J. Brill.

Rehman, A, \& Akhtar, M., (2012). The Mughal Gardens along the Grand Trunk Road in Pakistan and Afghanistan. Dumbarton Oaks. Retrieved from http://www.doaks.org/resources/middleeast-garden-traditions/

Ross, D. E. (1931). The Persians. London: Oxford at the Claridon Press,

Ruggles, F. D. (2008). Islamic Gardens and Landscapes. Philadelphia: University of Pennsylvania Press.

Stronach, D. (1994). Parterres and stone watercourses at Pasargadae: notes on the Achaemenid contribution to garden design. The Journal of Garden History, 14, 37-41.

Stuart, C. M. V. (1913). The Gardens of the Great Mughals. Soho Square: Adam and Charles Black.

Titley, N. M. (1979). Plants, and gardens in Persian, Mughal and Turkish Art. British Library Booklet.

Wescoat, J. L. (2011). The Changing Cultural Space of Mughal Gardens. In R. M. Brown \& D. S Hutton (Eds.), A Companion to Asian Art and Architecture. Oxford, UK: Wiley-Blackwell.

Wescoat, J. L. (1996). The Mughal garden: interpretation, conservation and implications. Ferozsons. 